\title{
THE CONCEPT OF POLARITY AND CENTRES OF POWER IN INTERNATIONAL RELATIONS
}

\author{
Nuke Faridha Wardhani ${ }^{1}$ \\ ${ }^{1}$ Master in International Affairs and Global Governance, Zhejiang University \\ 21822670@zju.edu.cn
}

\begin{abstract}
This paper explains the concept of polarity and centres of power where the poles are divided into three types in the international system. To be a great power, the states build and maintain their power capability in the system, and that capability is growing in every period, such as the emergence of nuclear power in the Cold War era. Furthermore, the scholars of international relations have different perceptions to determine the poles after the Cold War until this era whether the international system is unipolar or multipolar or even bipolar, as several countries are predicted to be potential great power in the forthcoming years.
\end{abstract}

Keywords: The concept of polarity, the Cold War Era, after the Cold War Era.

\section{INTRODUCTION}

The concept of polarity in international relations is used to describe the presence of one or more great powers dominating the international system. The great powers which have enormous capability are divided into several poles from different periods. More precisely, according to Goedele De Keersmaeker (2017: 232), "Polarity is about the number of great powers or polar powers." It can be seen that the international system tends to anarchy where there are no rules to control the state's behavior. Thus, it encourages the state as an actor to act freely to increase its capability to be a great power. Then, the poles appear to describe and also distinguish the status of the state.

At first, the scholars of international relations were inspired by natural science about the concept of polarity, for instance, the use of words "uni-“, "bi-“, "multi-“" (Keersmaeker, 2017: 13). Furthermore, the scholars created the consensus so that the concept can be proper from international relations' perspective. Thereby, there are commonly three types of polarity. They are one great power or one polar means unipolarity, two great powers or two poles mean bipolarity, and more than two great powers or more than two poles are known as multipolarity (Keersmaeker, 2017: 4). From that explanation, it can be conceived that the concept of polarity has never been a pure concept and is adapted from different science aspect.

In addition, there are three arguments about the concept of polarity, including the disparity between great powers and fewer powers. First, unipolarity is a condition where there is a wide power disparity between the great powers and all other states. Second, bipolarity is the two great powers in the international system having an approximately equal position, and there is wide power disparity with the fewer powers. Third, multipolarity is more than two great powers which have the approximately equal position, and there is the wide power disparity between the fewer powers in the international system (Levy 1985 cited in Mansfield 1993)." It is clearly seen that some scholars have a different definition of the concept of polarity, although the latter explanation is not clear about how much equal position in bipolar and multipolar conditions. 
As mentioned above, that the great powers have the capability. The capability is an important thing for the great powers to maintain their status. According to the Correlates of War index (COW), there are six indicators: total population, urban population, military expenditures, military personnel, energy consumption, iron and/or steel production (Keersmaeker, 2017: 36). However, most scholars define the polarity before the end of the Cold War, emphasizing economy and military power. These capabilities have significant roles to change power from one pole to the new pole (Kohout, 2003: 58). Furthermore, Waltz (1979 cited in Hopf 1991) also uses population figures and adds government revenues to determine a state's polar status. In addition, Wayman and Morgan (1990 cited in Mansfield 1993 ) pointed out that in the condition of bipolarity, the two great powers control at least 50 percent of the power capabilities. On the other hand, in multipolarity, the great powers have less than 50 percent of these capabilities.

From that explanation, we can see that the concept of polarity has various ways to describe the polar powers, especially describing the pole after the Cold War. Most scholars from the United States stated that the condition was unipolar, but some scholars argued that the system was divided into multipolar. This paper will explain more the condition after the Cold War by describing the types of polarity, such as unipolar, bipolar, and multipolar.

\section{CONCEPTUAL FRAMEWORK}

\section{Unipolarity}

Unipolarity is the condition where one state or a great power dominates the international system. It means that there is only one pole which Wohlforth (1999: 19) pointed out the state has an extensive material capability or too great to be counterbalanced, such as in economy and military, so that there is no balancing power. One of the instances in the United States in post-Cold War. There was a competition before between the two countries, particularly in economy and military capability. In late 1985, the military expenditures of the Soviet Union were limited, and it was followed by its economic capability so that the United States, with its ideology liberalism-capitalism, only became the great power.

There is the advantage from unipolarity moment as Wohlforth (1999: 20) said, "the unipolar system tends to create a peaceful international system and through hegemony theory and balance of power theory because powerful states foster international orders that are stable until differential growth in power produces a dissatisfied state with the capability to challenge the dominant state for leadership." Therefore, the presence of great power or only one pole creates an international system that is more stable and peaceful, also without a significant competitor. The only great power will maintain its status. However, the unipolarity moment is temporary and will emerge other powers to surpass the old players.

\section{Bipolarity}

Bipolarity is the condition when the poles are divided into two poles or two superpowers that are more powerful than others in the international system. According to Wagner (1993), bipolarity is a condition when most states are organized into two hostile coalitions, or there are only two nuclear 
superpowers. Hence, the two states are more powerful than the others. As we know that the balance of power is easier to achieve in a bipolar system (Kohout, 2003: 58), as there are only two great powers with approximately equal positions.

Some scholars have different arguments about stability in the concept of polarity. If Wohlforth pointed out that unipolar is a more stable condition, Kenneth Waltz (1979 cited in Hopf 1991) argued that the bipolar system is more stable than multipolar. Waltz emphasizes that stability is "the avoidance of great power war or wars between poles" and he believed if the wars occurred between two countries, the level of war is smaller under bipolarity (Waltz 1979 cited in Keersmaeker 2017). It means that there is a balance of power between the two great powers. For Waltz, bipolarity is a condition of only two great powers which act in the international system. If something occurs, that means "potentially of concern to both of them." Due to uncertainty being powerful in multipolar conditions, it leads the War to occur than in bipolarity system (Cederman, 1994).

Bipolarity is well known after World War II, especially in the late 1960s (Keersmaeker, 2017: 5). There were two superpowers, the United States and the Soviet Union, in the Cold War era. It is important to note that, at that time, the United States and the Soviet Union had much more powerful strength than other states, although Bipolar in the Cold War was a short period (Keersmaeker, 2017: 143). Furthermore, it can be seen that both countries also had opposed ideologies and different life, such as liberal-capitalism versus communism-socialism. Actually, there was no actual fighting at that moment, although Goedele De Keersmaeker (2017: 59) stated, "the armed forces were in the highest state of alert, amidst an overall economic and military mobilization." Thus, the main concentration in the world was only for the two countries.

To measure bipolarity, Wayman (1984 cited in Keersmaeker 2017) pointed out about the exixtence of the two superpowers that control more than 50 percent of the total capabilities of the great powers. There is an interesting part in the Cold War era, as Wagner said "the emergence of nuclear weapons technology." At that period was the first period where great powers used nuclear power. Thus, nuclear power is a new indicator of the capability that must be owned by a great power. Obviously, we can see that technology is growing fastly and it affects the transformation of international politics (Wagner, 1993: 82).

\section{Multipolarity}

Multipolarity is a condition in which more than two great powers or several poles in the international system. The term multipolarity began to appear in the 1960s and the early 1970s in The New York Times. That term was introduced by Nixon and Kissinger and was related to their foreign policy. They stated "the world remained militarily bipolar for the time being, but was quickly moving to multipolarity in economic and other fields" (Keersmaeker, 2017: 14). Furthermore, Aron (1962 cited in Keersmaeker, 2017: 18), also defined multipolarity as a system with several rival states with more or less similar resources. It is clearly seen that multipolar occurs when several great powers have similar capabilities dominating the international system. 
One of the instances of multipolarity is after the Cold War until this era. The international system might be multipolar, although it is still debatable by some analysts in international relations, as Goedele De Keersmaeker (2017: 3) stated that not all people agreed about multipolar in international system after the post-Cold War. Moreover, Waltz (1964 cited in Keersmaeker, 2017: 4) emphasized that multipolarity is less stable than bipolarity. In contrast, some of them who are not from the United States argued that the system is multipolar with the presence of Russia, China, and Japan. In addition, there are several potential countries such as India and Brazil in recent time. It can be seen in Rusia and China where that multipolarity has been a central foreign policy goal concerned by Yeltsin and Putin, as well as for China, multipolarity has been its foreign policy discourse since the late 1980s (Goedele De Keersmaeker, 2017: 3). On the other hand, if we use the indicator of power capability, North Korea also can be a potential great power, such as having nuclear power as a new indicator in this period.

\section{RESULT AND DISCUSSION}

\section{The Current Condition of the International System}

After the Cold War, mainly several years after the economy of the Soviet Union collapsed, there was a debate about the poles in the international system whether it was divided into unipolar or multipolar? Some scholars from the United States believed that the international system was unipolar even until now, but some scholars argued that the system was multipolar with the presence of the United States, Russia, and China. According to Krauthammer (1990/1991: 23), he believed that the international system after that time was unipolar, with the United States as the unchallenged superpower with its western allies. Although the previous player, such as Germany, Japan, Britain, and France, Russia still has several power capabilities, such as economy, military, and political, but all are in decline." (Krauthammer, 1990/1991: 24).

The presence of the United States as only a great power is not surprising as the country has the capabilities, for example, strong in economic, military (including weapons), diplomatic, political, education, cultural and nuclear power technology. Also, the country can prove to international society that "capitalism is better than socialism" and "democracy is better than dictatorship." (Jentleson and Weber 2008 cited in Schweller and Pu 2011). Not only share around 25 percent of the worldwide gross domestic product (GDP), but the United States has more than 50 percent of the GDP (Ikenberry et al., 2009 cited in Keersmaeker, 2017: 26). Furthermore, the United States uses its military and economic resources to dominate the Middle East, such as the U.S. invasion in Iraq. Although the United States has never passed 50 percent on its military capability (Barnett \& Duvall, 2005: 40) under the unipolarity position, the United States diplomats consistently enhance the security of the identities of China and India as potential great powers (Wohlforth, 2009: 53). It is important to note that the unipolarity moment for the United States will be not long-lasting as the internal state is fragile since Donald Trump was elected as a President whose policy sometimes is controversial especially facing climate change. 
Some of the potential countries are mentioned above. One of them is China which in recent years has become the biggest competitor for the United States. The emergence of China as a rising power is an interesting part of the international system. China is a new player in the international society with its rising economic development and military. It makes China now being the second-biggest military spender (Keersmaeker, 2017: 113). According to Yan Xuetong (cited in Schweller \& Xiaoyu 2011), one of the Chinese realists, "economically the world is already bipolar and China is the only country that can challenge the American strategic predominance if it allies with Russia." Indeed, China is increasing its capability as a great power, particularly in its economy, industry, and military, and creating advanced technology. It is supported by the country that has the largest population and territory. The country also actively participates and creates many international agendas (Schweller and Xiaoyu, 2011: 53). China seems confident and ambitious to increase its status as a great power. If China remains working hard to pursue its great power status, the international system can be divided into bipolar.

Moreover, there are various predictions about the polarity in the forthcoming years. Some scholars predicted that the system would be bipolar, such as in 2020, there will be two superpowers between the United States and China (Keersmaeker, 2017: 114). Some scholars predicted that the world would be multipolar. For instance, in November 2008, the National Intelligence Council (NIC) published The 'GlobalTrends 2025 ' report. It reported that the world would be multipolar by the year 2025. The same prediction from NIC in the 2012 version predicted China to be the largest economy in the world by 2030 (Keersmaeker, 2017: 198). Some scholars argued that the international system is still unipolar; for example, in the 2008 report, the USA would still play a prominent role in 2025 , but it would no longer be the only global player (Keersmaeker, 2017: 197). From that explanation, we can see that the poles in the international system nowadays and in the next few years is still debatable. Not only one type of polarity but there can be three types of poles to describe great powers that dominate the system.

\section{CONCLUSION}

To sum up, the concept of polarity emphasizes the number of great powers. To be a great power, the state as an actor has the capability, such as economy, military, population, territory, political and advanced technology, making the states more powerful than others. The capability in every period is different, for instance, the emergence of nuclear power technology in the Cold War era. It affects the indicator as a great power, and there is a transformation in international relations.

On the other hand, the definition of polarity in international relations has never been a clear answer, particularly in how to measure polarity as it is defined in various ways. Moreover, how long the durability of great powers and how much more powerful the state as a great power is still debatable. Even after the Cold War, some scholars are not sure about the condition of poles in the international system, whether unipolar or multipolar, and some of them also predicted in bipolar condition with the emergence of China and India as the potential great powers. Thus, the concept of polarity and centres 
of power is still growing, and it takes a consensus from all the scholars of international relations, particularly to determine a measurement in every pole.

\section{REFERENCES}

Barnett M \& Raymond D (2005) Power in International Politics. International Organization, 59(1) (Cambridge University Press on behalf of the International Organization Foundation), 39-75.

Cederman LE (1994) Emergent Polarity: Analyzing State-Formation and Power Politics. International Studies Quarterly, 38(4), 501-533.

Hopf T (1991) Polarity, The Offense Defense Balance, and War. The American Political Science Review, 85(2), 475-493.

Keersmaeker G (2017) Polarity, Balance of Power and International Relations Theory: Post-Cold War and the 19th Century Compared. Switzerland: Palgrave Macmillan.

Kohout F (2003) Cyclical, Hegemonic, and Pluralistic Theories of International Relations: Some Comparative Reflections on War Causation. International Political Science Review / Revue internationale de science politique, 24(1), 51-66.

Krauthammer C (1990/1991) The Unipolar Moment. Foreign Affairs, 70(1), 23-33.

Mansfield ED (1993) Concentration, Polarity, and the Distribution of Power. International Studies Quarterly, 37(1), 105-128.

Schweller RL \& Xiaoyu P (2011) After Unipolarity: China's Visions of International Order in an Era of U.S. Decline. International Security, 36(1), 41-72.

Wagner RH (1993) What was Bipolarity? International Organization, 47(1), 77-106.

Wohlforth WC (1999) The Stability of a Unipolar World. International Security, 24(1), 5-41.

Wohlforth WC (2009) Unipolarity, Status Competition, and Great Power War. World Politics, 61(1), International Relations Theory and the Consequences of Unipolarity (Cambridge University Press), 28-57. 